\title{
ASSESSING AND COMPARING THE LEVEL OF CORPORATE INTEGRITY PRACTICES IN MALAYSIAN STATUTORY BODIES
}

\author{
Nurhidayah Yahya ${ }^{1}$, Jamaliah Said ${ }^{2}$, \\ Nor Balkish Zakaria ${ }^{3}$ and Ruhaya Atan $^{4}$ \\ ${ }^{1}$ Accounting Research Institute, Universiti Teknologi MARA, Malaysia \\ E-mail: nurhidayah.y@gmail.com \\ ${ }^{2}$ Accounting Research Institute, Universiti Teknologi MARA, Malaysia \\ E-mail: jamaliah533@uitm.edu.my \\ ${ }^{3}$ Faculty of Accountancy, Universiti Teknologi MARA Johor, Malaysia \\ E-mail: balkish@uitm.edu.my \\ ${ }^{4}$ Accounting Research Institute, Universiti Teknologi MARA, Malaysia \\ E-mail: ruhayaa@gmail.com
}

\begin{abstract}
There are few frauds and unethical cases in the Malaysian public sector and that might have contributed to the lower score in the Corruption Perception Index (CPI) for Malaysia. Hence corporate integrity is crucial as one of the mechanisms to curb corruption. This study aimed to evaluate and compare corporate integrity practices of federal and state statutory bodies through a survey questionnaire. The measurement for corporate integrity practices is based on three dimensions; ethical foundation, ethical culture and ethical risk management. Based on 194 responses received from the top management of Malaysian statutory bodies, the overall corporate integrity practices showed an above-average score of 5.938 for federal and 5.896 state statutory bodies. The T-test results indicated that there is no significant difference between corporate integrity practices in federal and state statutory bodies. Despite the different resources they have, both types of statutory bodies seem to have and instil an equally high level of corporate integrity practices.
\end{abstract}

Keywords: corporate integrity practices, ethical foundation, ethical culture, ethical risk management, Malaysian statutory bodies

\section{$\underline{\text { ARTICLE INFO }}$}

\section{Article History:}

Received: 19 May 2020

Accepted: 28 August 2020

Published: 31 December 2020 


\section{INTRODUCTION}

Integrity has been widely discussed worldwide. Some research cover aspects of individual integrity and some cover at the corporate level. Both individual and corporate integrity practices are crucial as individuals run and manage organisations. It is a challenge to educate and instil integrity in individuals. Therefore, companies need to take extra steps to nurture corporate integrity practices and to inculcate integrity in individuals and curb unethical cases like corruption. Hence, it is vital to have corporate integrity practices in all organisations, especially public sector organisations. Public sector organisations are run and being managed using public money. Thus, corporate integrity practices must be upheld and cultivated to gain the public's trust and reputation. The low integrity shown by public organisations tarnishes their public sector reputation and eventually, the government (Seligson, 2002).

The concern on corruption is more significant because of the perception that corruption is assumed to be dangerous in some cases, its devastating effect on social life and restraint on the ability of a government to accomplish its functions (Banerjee, 2016; Zafarullah \& Siddiquee, 2001). Moreover, a study showed that countries with a high level of corruption attract less investment than less corrupt countries (Sarkar \& Hasan, 2001). Another study found that when corruption increased by $2 \%$, the growth rate decreased by $0.5 \%$ and investment decreased by $4 \%$ (Mauro, 1997). The World Bank also stated that countries involved in corruption lost between $2 \%$ to $4 \%$ of their Gross Domestic Product (GDP). It is estimated that organisations lose $5 \%$ of revenue to fraud each year in which corruption was the most common scheme in every global region, asset misappropriation schemes were the most common scheme and least costly, and finally, financial statements fraud schemes are least common and most costly (Association of Certified Fraud Examiners, 2020). Therefore, corporate integrity is crucial for organisational performance, and eventually, it will lead to the overall improvement in a country's economic performance too. Lack of integrity in an organisation will lead to not being honest, behavioural inconsistency, and affect the overall organisation integration system (Audi \& Murphy, 2006).

Besides, having a high level of corporate integrity shows a low corruption level of a nation (Langseth, 1999; Ucar \& Staer, 2020). 
Transparency International had created a Corruption Perception Index (CPI) to measure the public's perception of corruption. Table 1 shows the CPI rank and scores for Malaysia, as reported by Transparency International. It is shown that Malaysia's CPI deteriorated and decreased in scores, signalling that Malaysia does have issues with integrity in which public organisations have contributed to the decline.

Table 1: Rank and Scores of Malaysia's CPIs

\begin{tabular}{lcl}
\hline Year & Rank & Scores \\
\hline 2013 & $53 / 177$ & $50 / 100$ \\
2014 & $50 / 175$ & $52 / 100$ \\
2015 & $54 / 167$ & $50 / 100$ \\
2016 & $55 / 176$ & $49 / 100$ \\
2017 & $62 / 180$ & $47 / 100$ \\
2018 & $61 / 180$ & $47 / 100$ \\
2019 & $51 / 180$ & $53 / 100$ \\
\hline
\end{tabular}

Note: The sources are from Transparency International

In Malaysia, public sector organisations are segregated into multiple groups like ministries, statutory bodies and local authorities. This study focussed on statutory bodies. Malaysian statutory bodies are divided into two tiers, federal and state. Federal statutory bodies are accountable to a more significant coverage area, community and budget and are liable to their respective federal ministries and Parliament. On the other hand, state statutory bodies are responsible to the State Legislative Assembly and only serve their states.

There are issues and problems of integrity among statutory bodies in Malaysia. For example, for federal statutory bodies, the Federal Land Development Authority's (FELDA) sturgeon fish farming project amounting to RM47.6 million is a case of abuse of power and misappropriation of funds done by FELDA's former general manager, former deputy director and officers ${ }^{1}$. An example for state statutory bodies is the case of misappropriation of funds in the Bumiputra Quota Contribution Payment

1 Retrieved from http://www.nst.com.my/news/2017/01/207460/sturgeon-farming-project-how-felda5-beat-system 
Trust Fund of Johor ${ }^{2}$. The funds of the trust amounting to RM822,640 were allegedly misused for a working trip, which is not in line with the purpose of the trust. Both cases are still under investigation.

The review above shows that both federal and state statutory bodies have issues with corporate integrity practices. However, there is no empirical data to support that between the two, which statutory body has more problems with corporate integrity practices. Empirical data is needed to compare the practices of both types organisations and provide a better understanding.

This study used primary data as a method of data collection. The study aimed to assess the level of corporate integrity practices for both federal and state statutory bodies. Later, the scores were compared to distinguish whether there are differences between both statutory bodies. This can be an indicator for further improvements in the future for Malaysian statutory bodies.

\section{FEDERAL AND STATE STATUTORY BODIES}

Statutory bodies are public organisations conducting government activities and are subject to executive and legislative control (Seidman, 1954). Statutory bodies emphasis on the process, which promotes societal value and have a high level of citizen involvement and responsiveness to the needs and interest of society (Denhardt, 2008). Government grants finance them, and they are also expected to generate their own income. The statutory bodies' business activities comprise many arenas that involve demands from government, state, market and society (Thynne, 2006). The public sector that includes government agencies and statutory bodies play a very important role in the development and management of a state and the whole nation. In terms of financial management, statutory bodies have their own financial regulations, systems and procedures and accounting policies. They are subjected to incorporation Acts or subsidiary incorporation legislation which set out the purpose and specific powers of autonomy, and they

2 Retrieved from https://www.thestar.com.my/news/nation/2018/12/09/macc-investigatesalleged-misappropriation-of-johor-bumiputra-trust-fund/, https://www.bharian.com.my/berita/ wilayah/2018/12/504713/sprm-diminta-siasat-tabung-amanah-sumbangan-kuota-bumiputera-johor, and https://www.nst.com.my/news/nation/2018/12/438957/investigation-fund-misappropriationearly-stage-johor-macc 
function according to their objectives. Nevertheless, the Board of Directors is established and authorised for management, administration, and activities of statutory bodies.

In Malaysia, there are two tiers of statutory bodies which are federal and state level statutory bodies. The federal statutory bodies are set up by Parliament and incorporated following the Federal laws to execute government policies through their programmes and activities (National Audit Department Malaysia, 2015). Each federal statutory body is placed under a ministry in charge as required by the incorporation legislation. They have subsidiaries and branches to ensure the efficiency of services delivered to the public. They are formed to be the arm and legs of every ministry to perform and carry out the task in providing services to the public. An example of federal statutory bodies is the Central Bank of Malaysia, which is a statutory body under the Ministry of Finance.

In federal statutory bodies, the Board of Directors consist of representatives from the Ministry of Finance, representatives from related ministries, Chief Executive Officer and his deputies, secretary, government officers and corporate members who have relevant expertise in the statutory body's activities. The selection and termination of board members are under the jurisdiction of the Minister. Federal statutory bodies submit their audited financial statement to their respective ministers. The ministers later table them in the Parliament.

State statutory bodies are incorporated according to each state government's enactments and laws. Their main activities are for the maintenances and development of the states. Examples of state statutory bodies are the Selangor State Development Corporation for the state of Selangor, the Sabah Rubber Industry Board for the state of Sabah and the Kelantan Public Library Corporation for the state of Kelantan. The Board of Directors is chaired by the Chief Minister of the state, and the deputy would be the secretary of the state government. The Board members consist of directors from related departments of the statutory bodies' business activities, and some have representatives from relevant federal ministries. Their audited annual reports are tabled in the State Legislative Assembly. 
Though federal statutory bodies and state statutory bodies are accountable to different authorities and they are different in term of enactment and board compositions, both are established to deliver government policies through their operations of services, programmes and activities. It is very challenging for statutory bodies since their operations cover and involve diverse scopes. Statutory bodies are also complicated because they are involved with government-related initiatives, developments in information technology and communication, and higher demands for assurance and results (Barrett, 2002). A comparison study would have a practical contribution to both statutory bodies for their corporate integrity practices analyses. Corporate integrity practices are explained in the following section.

\section{LITERATURE REVIEW}

\section{Corporate Integrity Practices}

Corporate integrity is known generally as business ethics, honesty and moral virtue (Audi \& Murphy, 2006; Petrick \& Quinn, 2000; Shu, Chen, Lin, \& Chen, 2018; Zafarullah \& Siddiquee, 2001). It also defined as the quality of corporate moral self-governance (Asawo, 2011; Guiso, Sapienza, \& Zingales, 2015; Petrick \& Quinn, 2000) that relates to moral conscientiousness, moral accountability, moral commitment, and moral coherence combined with the law (Paine, 1994). It covers wholeness and coherence; professional responsibility; moral reflection; values, laws and rules; moral values and norms; and exemplary behaviour (Huberts, 2018). Corporate integrity is seen as intrinsic value or asset to an organisation (Koehn, 2005; Zafarullah \& Siddiquee, 2001). Thus, it is vital for organisations to have corporate integrity practices, especially in public sector organisations.

Fraud and unethical behaviour can drain an organisation's resources, and potential foreign investors might be inclined not to invest in countries that are exposed to high fraud (Dutta, Kar, \& Saha, 2017; Rossouw, Van Vuuren, Abdullah, \& Mohamad Zainol Abidin, 2011). The corporate values statements should not be built at the cost of avoidable ambiguity and put integrity at stake. Thus, corporate integrity in statutory bodies is 
essential. Corporate integrity practices need to be upheld as the statutory bodies are operating using public money and must manage the resources efficiently and ethically. Integrity and following ethical codes lead to fulfilling organisational objectives and desired organisational performance and accountability (Lussier \& Achua, 2013; Ryan \& Ng, 2000). However, the public organisation performance is far from satisfactory because the government has failed to emerge as a competent body in controlling and combating administrative corruption (Dutta \& Sobel, 2016; Pailler, 2018; Zafarullah \& Siddiquee, 2001).

For public organisations like statutory bodies, those that have credible governance framework will get support from their stakeholders due to accountability assurance with corporate integrity practices. This validates the ethical allocation of resources on the economy, efficiency, and effectiveness of public funds (Barrett, 2002; Shu et al., 2018). Therefore, public organisations must uphold high corporate integrity level because it will increase their organisational performance and built a reputation among the public (Brenkert, 2004a, 2004b). Integrity also expands the organisation's sense of self-worth (Mintrop, 2012).

The benchmarks of corporate integrity practices cover the aspect of ethical foundation, ethical culture and ethical risk management. A concrete ethical foundation is crucial to develop an ethical culture and further ethical risk management. The challenge to develop organisation systems like the ethical foundation is integrating the moral dimension of economic transactions into an organisation's strategies, policies, and procedures; therefore it needs to be anchored to the top management or the leadership of the organisation (Carasco-saul, Kim, \& Kim, 2015; Wieland, 2005). The ethical foundation is the guidance for integrity in an organisation and a reflection of top management's beliefs that shape the organisation's ethical culture (Adro \& Leitão, 2020; Arjoon, 2006; Ilyas, Abid, \& Ashfaq, 2020)integrity and intellectual honesty. This paper highlights the drawbacks of an excessively heavy reliance on rules-based approaches that increase the cost of doing business, overshadow essential elements of good corporate governance, create a culture of dependency, and can result in legal absolutism. The paper makes the case that the way forward for effective corporate governance is to strike an optimal balance between rules-based and principles-based approaches. The recent corporate 
scandals have demonstrated that the ethical ODNA is critical to the driving force and basis of legal and regulatory requirements. Effective governance means adhering to ethical principles, not merely complying with rules, and is a crucial guardian of a firm's reputation and integrity. It is through an effective corporate governance program (that is, one that optimally captures and integrates the appropriate aspects of rules-based and principles-based approaches, and identifies and assesses the related risks.

Ethical culture is developed from an ethical foundation. For the ethical foundation to be functional and be part of the ethical culture instilled in the organisation, ethical training and education need to be provided (Arjoon, 2006; Ilyas et al., 2020)integrity and intellectual honesty. This paper highlights the drawbacks of an excessively heavy reliance on rules-based approaches that increase the cost of doing business, overshadow essential elements of good corporate governance, create a culture of dependency, and can result in legal absolutism. The paper makes the case that the way forward for effective corporate governance is to strike an optimal balance between rules-based and principles-based approaches. The recent corporate scandals have demonstrated that the ethical ODNA is critical to the driving force and basis of legal and regulatory requirements. Effective governance means adhering to ethical principles, not merely complying with rules, and is a crucial guardian of a firm's reputation and integrity. It is through an effective corporate governance program (that is, one that optimally captures and integrates the appropriate aspects of rules-based and principles-based approaches, and identifies and assesses the related risks. Further, the organisation must have competent integrity communication and information management to effectively project corporate integrity practices to its stakeholders (Asawo, 2011; Brown, 2005). Once integrity becomes part of organisational culture, employees will embrace their code of conduct (Gorelick, 2004; Ilyas et al., 2020). This will further improve the organisation's societal activities and reduce punishment from unethical activities.

Finally, ethical culture helps to advance ethical risk management. Ethical risk management involves some control upon the organisation. Whistleblowing is part of the control (Mohd Noor \& Mansor, 2019; Wieland, 2005). They were having whistleblowing and proper investigation procedures, secure confidentiality, openness, responsiveness and honesty of 
the organisation's ethics. The organisation would have learnt their lessons and anticipated areas of high integrity risk areas. Hence, with the fulfilment of ethical risk management, an organisation would be able to eradicate fraud, bribery and corruption in its operations (Dubinsky \& Richter, 2015).

There were lots of initiatives done by the Malaysia government to combat corruption in a coherent way. Several institutions have been established to accelerate the fight against corruption. Among those are the Public Complaints Bureau, Malaysia Institute of Integrity (IIM), Malaysian Anti-Corruption Commission (MACC), Malaysian Administrative Modernisation and Management Unit (MAMPU), Malaysian AntiCorruption Academy (MACA), Government transformation Plan (GTP) and the National Key Results Area (NKRA) Corruption Monitoring and Coordination Division (Ismail, Ngah, Hassan, Abdullah, \& Salleh, 2011; Joseph et al., 2019; Rosli, Aziz, Mohd, \& Said, 2015; Said \& Omar, 2014). Also, other government institutions like the Auditor General's Office, Attorney General's Chambers, the Judiciary, the Public Accounts Committee, police, customs, NGO like Suara Rakyat Malaysia SUARAM (Malaysian Voice) and professional bodies like Transparency International Malaysia Chapter play essential roles to combat corruption and uphold integrity (Joseph et al., 2019).

Further, for statutory bodies, most of them have an integrity and governance office department. MACC had designed a program with IIM and is being conducted by MACA to train Certified Integrity Officers (CeIO) who will in charge of a department with the title of Chief Integrity Officer (CIO). In Malaysian public sector organisations, the CIOs were found to be competent and high performers (Sajari, Haron, Ismail, \& Chambers, 2019). A qualified and competent CeIO would have a good understanding of Integrity Management, a proper legal system, enforcement and monitoring program, and the ability to build a plan of action for integrity ${ }^{3}$. This initiative is to ensure that statutory bodies have effective anti-corruption programs. The department works to maintain the ethical culture of civil servants (Sajari, Haron, \& Ismail, 2016).

For the purpose of the study, the surveys were distributed online, and respondents' emails were gathered from the organisations' websites. The 3 Retrieved from https://www.sprm.gov.my/index.php/en/corporate-info/message-from-the-chiefcommissioner/142-knowledge/771-certified-integrity-officer-ceio 
researcher found that through the statutory bodies' website, most federal statutory bodies had implemented proper integrity units or departments. However, most state statutory bodies did not have such a unit. This might be due to the size of the organisations where federal statutory bodies are bigger and need proper integrity units to handle complaints or reports.

In addition, one of the noble initiatives is introducing the Corporate Integrity Pledge in 2010 by IIM; a voluntarily pledge undertaken by the business community in committing and implementing good business ethics. There is also Malaysia's Integrity Pact whereby related parties that do business with the organisations are also required to sign the pact. It is a formal tool to bind participation in public sector procurements to comply with contracts and conduct business without corruption.

Therefore, having corporate integrity practices which consist of an ethical foundation, ethical culture and ethical risk management elements are vital for organisations like statutory bodies. Though many initiatives have been implemented and initiated, there are still many reports and issues of lack of integrity practices in statutory bodies reported in the Auditor's General Report and news. Henceforth, it is extremely crucial to conduct such an empirical investigation.

\section{METHODOLOGY}

\section{Data Collection}

Questionnaires were distributed to 291 Malaysian statutory bodies, through an online survey from November 2017 to February 2018. There were 127 federal statutory bodies and 164 state statutory bodies. The respondents were Chief Executive Officer (CEO) or equivalent. They were chosen as the respondent of the study as they knew the matters of the organisation and are aware of organisational updates and regulatory requirements for the organisations.

\section{Measurement for Variables}

The questionnaire for corporate integrity and its measurement was adopted with modifications from the Global Ethics and Integrity Benchmark 
by Dubinsky and Richter (2015). The corporate integrity practices were measured through three dimensions of ethical foundation, ethical culture and ethical risk management.

Seven Likert scales were used to assess the level of agreement or disagreement of respondents for each question. The scale measured as $1=$ Strongly disagree, $2=$ Somewhat disagree, $3=$ Slightly disagree, $4=$ Neither disagree nor agree, $5=$ Slightly agree, $6=$ Somewhat agree, $7=$ Strongly agree.

\section{Data Analysis}

A descriptive analysis was conducted. Data reliability of the current study was measured by utilising the Cronbach's alpha test. Later, the independent T-test was conducted, and the effect size was done accordingly to indicate whether there was a significant difference between the level of corporate integrity practices of federal and state statutory bodies.

\section{RESULTS}

One hundred ninety-four responds were gathered from two hundred and ninety-one surveys distributed, which give a $66.7 \%$ response rate. Responses from federal statutory bodies were 116 (59.8\%), and state statutory bodies $78(40.2 \%)$. The demographics of the respondents is shown in Table 2.

Table 2: Respondents' Demographic Information

\begin{tabular}{lcccc}
\hline & $\begin{array}{c}\text { Demographic profiles } \\
\text { Frequency }(\mathbf{N}=194)\end{array}$ & Federal & State & Percent (\%) \\
\hline Gender & Male & 58 & 51 & 56.19 \\
& Female & 58 & 27 & 43.81 \\
\hline Age & Less 30 years old & 10 & 4 & 7.22 \\
& 30-40 years old & 42 & 28 & 36.08 \\
& 41-50 years old & 32 & 22 & 27.84 \\
& 51-60 years old & 29 & 21 & 25.77 \\
& More than 60 years & 3 & 3 & 3.09 \\
\hline Academic qualification & Bachelor's degree & 60 & 50 & 56.69 \\
& Master's degree & 42 & 22 & 33
\end{tabular}




\begin{tabular}{lcccc} 
& Professional & 9 & 4 & 6.7 \\
& Others & 5 & 2 & 3.61 \\
\hline Number of years in the & Less than 5 & 49 & 42 & 46.91 \\
current position (years) & $5-10$ & 31 & 18 & 25.26 \\
& $11-15$ & 13 & 8 & 10.82 \\
& $16-20$ & 6 & 5 & 5.67 \\
& More than 20 & 17 & 5 & 11.34 \\
\hline
\end{tabular}

The reliability of the items in the questionnaire was excellent as the Cronbach's alpha was 0.957 (Nunnally, 1978). Therefore, the measurements were valid and reliable.

Table 3: Descriptive Analysis of Corporate Integrity Practices and Corporate Integrity Practices' Dimensions

\begin{tabular}{lccccc} 
& Minimum & Maximum & Mean & Std. Dev. & Variance \\
\hline Ethical foundation & 2.00 & 7.00 & 5.9472 & .98570 & .972 \\
Ethical culture & 1.60 & 7.00 & 5.9124 & .97020 & .941 \\
Ethical risk management & 2.00 & 7.00 & 5.9093 & 1.08385 & 1.175 \\
Corporate integrity practices & 2.29 & 7.00 & 5.9212 & .96176 & .925 \\
\hline
\end{tabular}

Table 3 describes the score for each corporate integrity practices elements, and the overall corporate integrity practices score for both federal and state statutory bodies. All scores for each dimension and total corporate integrity were above average. Among the three dimensions of corporate integrity practices, the first ranked is the ethical foundation, followed by ethical culture and finally, ethical risk management. The results were further grouped into federal and state statutory bodies, as shown in Table 4. 
Table 4: Mean Analysis of Corporate Integrity Practices and Corporate Integrity Practices' Dimensions Based on Federal and State Statutory Bodies

\begin{tabular}{llcc}
\hline & & Mean & Std. Dev. \\
\hline Ethical foundation & Federal Statutory Bodies & 5.9569 & .94999 \\
& State Statutory Bodies & 5.9327 & 1.04266 \\
Ethical culture & Federal Statutory Bodies & 5.9259 & .88956 \\
& State Statutory Bodies & 5.8923 & 1.08481 \\
Ethical risk management & Federal Statutory Bodies & 5.9362 & .98743 \\
& State Statutory Bodies & 5.8692 & 1.21883 \\
Corporate integrity & Federal Statutory Bodies & 5.9384 & .88505 \\
practices & State Statutory Bodies & 5.8956 & 1.07119 \\
\hline
\end{tabular}

Table 4 describes the score for each corporate integrity practices elements, and the overall corporate integrity practices score for both federal and state statutory bodies. All scores for each dimension and total corporate integrity were above average. Notably, for federal statutory bodies, between the three dimensions of corporate integrity practices, the first ranked was ethical foundation, followed by ethical risk management and finally, ethical culture. As for state statutory bodies, the ranking of the dimension was ethical foundation, ethical culture and ethical risk management. The total score of corporate integrity practices showed that federal statutory bodies scored higher than state statutory bodies.

Next, an independent T-test was conducted to compare corporate integrity practices mean scores between federal and state statutory bodies. The test was conducted to compare both groups' mean as the responses were more than 30 ; hence, normality would not be an issue. The results are shown in Table 5. 


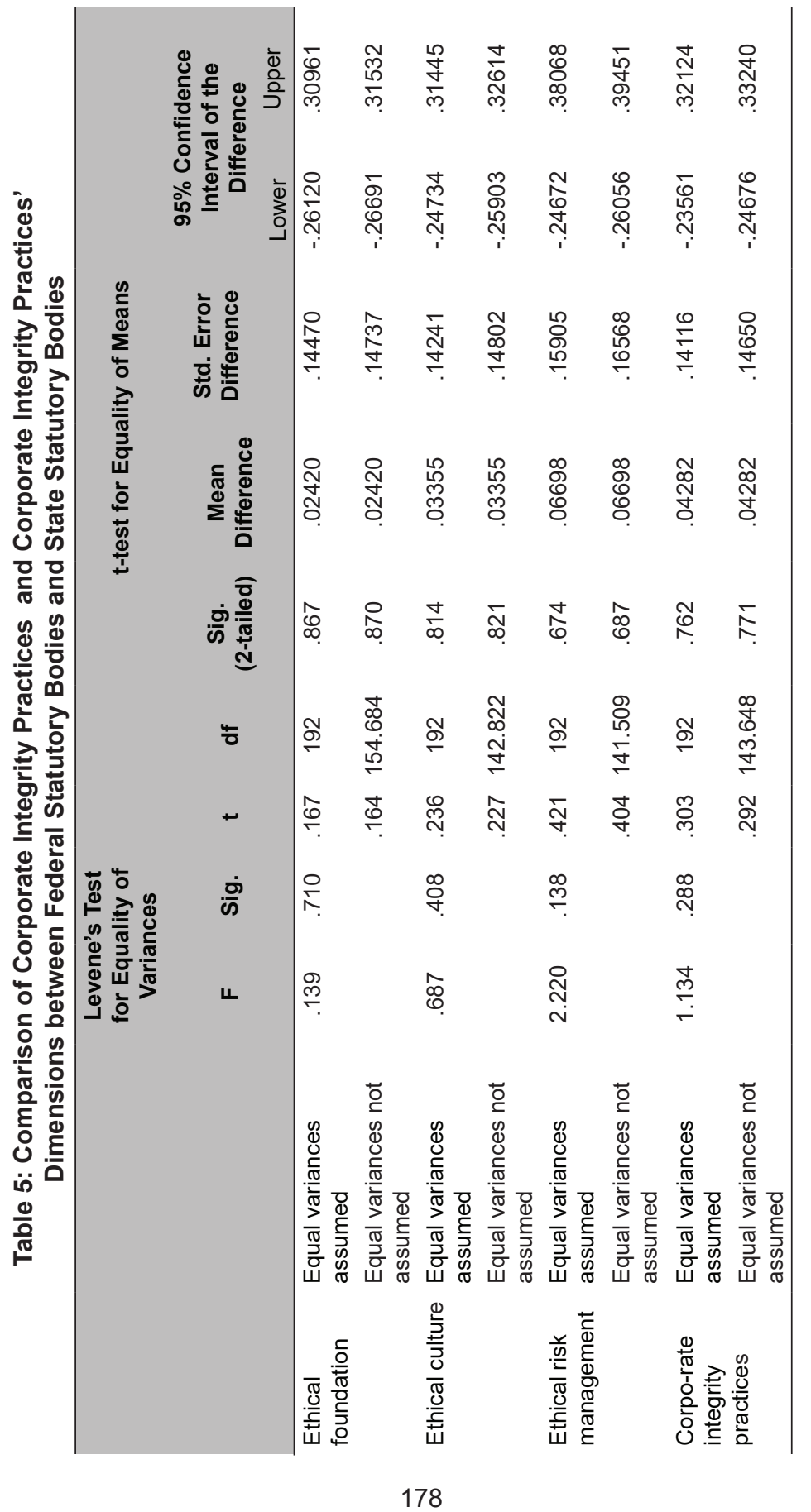


For the differences between federal statutory bodies and state statutory bodies, the ethical foundation's $\mathrm{p}>.05$, which was .710 ; hence, Equal variances assumed. There was no significant difference in the ethical foundation's score between federal $(\mathrm{M}=5.9569, \mathrm{SD}=.94999)$ and state statutory bodies $(\mathrm{M}=5.9327, \mathrm{SD}=1.04266)$; $\mathrm{t}(192)=.167, \mathrm{p}=.867$ (twotailed).

As the ethical culture's $\mathrm{p}>.05$, which was .408; hence, Equal variances assumed. There was no significant difference in the ethical culture score between federal $(\mathrm{M}=5.9259, \mathrm{SD}=.88956)$ and state statutory bodies $(\mathrm{M}=5.8923, \mathrm{SD}=1.08481) ; \mathrm{t}(192)=.236, \mathrm{p}=.814$ (two-tailed).

For the ethical risk management's $\mathrm{p}>.05$, which was .138; hence, Equal variances assumed. There was no significant difference in the ethical risk management score between federal $(\mathrm{M}=5.9362, \mathrm{SD}=.98743)$ and state statutory bodies $(\mathrm{M}=5.8692, \mathrm{SD}=1.21883) ; \mathrm{t}(192)=.421, \mathrm{p}=.674$ (twotailed).

Finally, the corporate integrity practices' $\mathrm{p}>.05$, which was .288 ; hence, Equal variances assumed. There was no significant difference in the corporate integrity practices score between federal $(\mathrm{M}=5.9384, \mathrm{SD}=.88505)$ and state statutory bodies $(\mathrm{M}=5.8956, \mathrm{SD}=1.07119) ; \mathrm{t}(192)=.303, \mathrm{p}=.762$ (two-tailed).

Further, the effect size for independent sample T-test provided the magnitude of differences between the two groups (Pallant, 2016). It could be known by calculating eta squared. The calculation for eta squared is as follows:

$$
\text { Eta squared }=\mathrm{t}^{2} / \mathrm{t}^{2}+(\mathrm{N} 1+\mathrm{N} 2-2)
$$

The Eta squared calculated for the ethical foundation was .0001, ethical culture was .0002 , ethical risk management was .0009 , and corporate integrity practices was .0004. Hence, as stated in Pallant (2016) that the magnitude of differences in the means of corporate integrity practices between federal statutory bodies and state statutory bodies (Mean Difference $=.04282,95 \%$. Confidence Interval $=-.23561$ to .32124 ) was very small (eta squared $=.0004)$. 


\section{DISCUSSION}

Based on the mean results of corporate integrity practices, both federal and state statutory bodies scored above average. Both ranked ethical foundations as first, but federal statutory bodies ranked ethical risk management as second and ethical culture as last. As for state statutory bodies ethical culture as second and finally ethical risk management. An above-average score showed that Malaysian statutory bodies had put proper initiatives and implementation for corporate integrity practices in their organisations. This is in line within the strong will of the government to combat corruption, especially in public service organisations.

This can be seen through the appointment of a CIO in each federal statutory body. The government took the lead to have such a position in the statutory bodies offices to implement, teach, train and nurture the culture of integrity among employees in the organisation. Ongoing integrity training is also being conducted throughout the whole organisation. The $\mathrm{CIO}$ also take care of any ethical reports lodged by the stakeholders in the statutory bodies on integrity matters. The CIO is seen as an individual with a significant role and duty in ensuring that ethics are applied within the organisation (Sajari et al., 2019).

However, for state statutory bodies, it is not compulsory to have a separate and self-integrity officer in the organisation. The size of state statutory bodies is smaller than federal statutory bodies. Hence the integrity officers are sometimes their CEOs themselves or their internal auditors rather than another person in charge of a CIO position. Nevertheless, it is part and parcel of statutory bodies activities to implement and instil corporate integrity practices in their daily operations.

However, for further progress, each statutory body can improve in dimension which the least they scored. Federal statutory bodies might need to focus more on ethical culture while state statutory bodies on ethical risk management. While maintaining the other aspect of corporate integrity practices, the least scored dimensions and elements of the dimension need to be upgraded. It will contribute to a higher score of corporate integrity practices in the future. Each organisation ought to facilitate and support ethical conducts since they are so essential and must not forgo any useful 
instrument to achieve it (Audi \& Murphy, 2006). It is for the organisations to be better both at the corporate and individual level, which is the civil servants.

Corporate integrity is a challenge to the organisations to achieve their targeted performance (Brenkert, 2004b). Still, it is an effective means to achieve economic success in an organisation (Bouckaert \& Van de Walle, 2003). Corporate integrity helps firms to achieve better their goals of social ethics (Francés-Gómez, 2003; Wan, Chen, \& Ke, 2020). Integrity earned stakeholders' trust (Audi \& Murphy, 2006). This is because some of the corporate integrity elements providing protection from the retribution of suspected misconduct reported and supports human rights and environmental sustainability. Any breach of integrity can cause damage to the organisation itself, the employees and the stakeholders (Du, Li, Lin, \& Wang, 2018; Kaptein, 1999).

As suggested by Transparency International, corruption could be prevented through transparency and effective access to information and open government practices. Further, it was suggested to adopt a zero-tolerance policy for corruption in public services and apply appropriate sanctions (Transparency International, 2017). Although corporate integrity is not part of the law and can never be reduced to legal compliance (KrambiaKapardis, 2016), it trains the organisation to comply with the law and attain accountability (Guinn, 2000). Corporate integrity helps organisations to achieve their goals of social ethics (Francés-Gómez, 2003). Corporate integrity involves a country and the government's reputation and also will lead to public organisational performance (Barrett, 2001; Zafarullah \& Siddiquee, 2001). Hence, every organisation must have a cost-effective compliance program and compliance officer (Steinberg, 2011). The government should invest and maintain resources like having a corporate integrity officer or any similar officer with an integrity task in each statutory body.

\section{CONCLUSION}

Though the overall corporate integrity practices score was above average, many more improvements on the low ranked elements like ethical culture and 
ethical risk management, and maintenance of high scored dimensions can be done by statutory bodies. The result of the study would help policymakers to take proactive steps to improve corporate integrity practices in the statutory bodies and reduce unethical cases. Further, the government must revise the ways and systems with current emerging trends of globalisation and the information age to uphold corporate integrity practices.

Besides, this study contributes to the body of knowledge and more empirical evidence on corporate integrity practices. There are many studies in the area of corporate integrity practices in Malaysia, and this research focuses on statutory bodies covering both federal and state-level assessment and comparison. However, the result of the study should not be used to generalise to the whole Malaysian public sector organisations. A future study can be conducted to other public sector organisations like the ministries and local authorities for further insights.

\section{REFERENCES}

Adro, F. J. N. do, \& Leitão, J. C. C. (2020). Leadership and organizational innovation in the third sector: A systematic literature review. International Journal of Innovation Studies, 4(2), 52-67.

Arjoon, S. (2006). Striking a balance between rules and principles-based approaches for effective governance: A risks-based approach. Journal of Business Ethics, 68, 53-82.

Asawo, S. P. (2011). Corporate integrity and company-community conflict management in the Niger Delta Region of Nigeria. Journal of Leadership Accountability and Ethics, 8(3), 77-88.

Audi, R., \& Murphy, P. E. (2006). The many face of integrity. Business Ethics Quarterly, 16(1), 3-21.

Banerjee, R. (2016). Corruption, norm violation and decay in social capital. Journal of Public Economics, 137, 14-27.

Barrett, P. (2001, April). Corporate governance in the public sector context. Presented at the MinterEllison Seminar Series. Retrieved from https:// 
www.anao.gov.au/sites/default/files/Barrett_corporate_governance_in the_public_sector_context_2001.pdf

Barrett, P. (2002, June). Achieving better practice corporate governance in the public sector. Pesented at the International Quality \& Productivity Centre Seminar. Retrieved from https://www.anao.gov.au/sites/ default/ files/Barrett_achieving_better_practice_corporate_governance_in_the public_sector_2002.pdf

Bouckaert, G., \& Van de Walle, S. (2003). Quality of public service delivery and trust in government. In A. Salminen (Ed.), Governing Networks: EGPA Yearbook (pp. 299-318). Amsterdam: IOS Press.

Brenkert, G. G. (Ed.) (2004a). Corporate integrity and accountability. Thousand Oaks, US: SAGE Publications Inc.

Brenkert, G. G. (2004b). The need for corporate integrity. In G. G. Brenkert (Ed.), Corporate integrity and accountability (pp. 1-10). Thousand Oaks, US: SAGE Publications Inc.

Brown, M. T. (2005). Corporate integrity : Rethinking organizational ethics and leadership. (1st ed.). New York, US: Cambridge University Press.

Carasco-saul, M., Kim, W., \& Kim, T. (2015). Leadership and employee engagement: Proposing research agendas through a review of literature. Human Resource Development Review, 14(1), 38-63.

Denhardt, R. B. (2008). Theories of public organizations (5th ed.). Belmont: Thomson Wadsworth.

Du, J., Li, W., Lin, B., \& Wang, Y. (2018). Government integrity and corporate investment efficiency. China Journal of Accounting Research, $11(3), 213-232$.

Dubinsky, J. E., \& Richter, A. (2015). Global ethics and integrity benchmarks. Retrieved from http://www.qedconsulting.com/assets/ globalethicsand integritybookmarks_2015.pdf 
Dutta, N., Kar, S., \& Saha, S. (2017). Human capital and FDI : How does corruption affect the relationship?. Economic Analysis and Policy, 56, $126-134$.

Dutta, N., \& Sobel, R. (2016). Does corruption ever help entrepreneurship? Small Business Economics, 47, 179-199.

Francés-Gómez, P. (2003). Some difficulties in Sacconi's view about corporate ethics. Journal of Business Ethics, 42(2), 165-180.

Gorelick, J. (2004, October). Keepers of the corporate conscience: The role of the board in ethical oversight. Presented at the Ragtheon Lectureship in Business Ethics, Center for Business Ethics, Bentley College, Massachusetts.

Guinn, D. E. (2000). Corporate compliance and integrity programs: The uneasy alliance between law and ethics. HEC Forum, 12(4), 292-302.

Guiso, L., Sapienza, P., \& Zingales, L. (2015). The value of corporate culture. Journal of Financial Economics, 117(1), 60-76.

Huberts, L. W. J. C. (2018). Integrity: What it is and why it is important. Public Integrity, 20, S18-S32.

Ilyas, S., Abid, G., \& Ashfaq, F. (2020). Ethical leadership in sustainable organizations: The moderating role of general self-efficacy and the mediating role of organizational trust. Sustainable Production and Consumption, 22, 195-204.

Ismail, R., Ngah, N. E., Abdullah, I. H. T., Salleh, A., Ibrahim, N., Tajuddin, N. A., ... \& Zin, S. M. (2011). The perception of integrity of three public agencies in Kuala Terengganu. World Applied Sciences Journal, 12, $60-63$.

Joseph, C., Gunawan, J., Madi, N., Janggu, T., Rahmat, M., \& Mohamed, N. (2019). Realising sustainable development goals via online integrity framework disclosure: Evidence from Malaysian and Indonesian local authorities. Journal of Cleaner Production, 215, 112-122. 
Kaptein, M. (1999). Integrity management. European Management Journal, 17(6), 625-634.

Koehn, D. (2005). Integrity as a business asset. Journal of Business Ethics, $58,125-136$.

Krambia-Kapardis, M. (2016). Corporate fraud and corruption: A holistic approach to preventing financial crises (1st Ed.). New York: Palgrave MacMillan.

Langseth, P. (1999, November). Prevention: An effective tool to reduce corruption. Paper presented at the ISPAC Conference on Responding to the Challenge of Corruption. Retrieved from https://www.unodc.org/ documents/corruption/Publications/1999/Prevention_An_Effective_ Tool_to_Reduce_Corruption.pdf

Lussier, R. N., \& Achua, C. F. (2013). Leadership, theory application \& skill development (5th ed.). Mason, $\mathrm{OH}$ : South-Western Cengage Learning.

Mauro, P. (1997). Why worry about corruption?. Washington: International Monetary Fund.

Mintrop, H. (2012). Bridging accountability obligations, professional values and (perceived) student needs with integrity. Journal of Educational Administration, 50(5), 695-726.

Mohd Noor, N. R. A., \& Mansor, N. (2019). Exploring the adaptation of artificial intelligence in whistleblowing practice of the internal auditors in Malaysia. Procedia Computer Science, 163, 434-439.

National Audit Department Malaysia. (2015). Auditor General's Report: Synopsis on the Audit of Activities of the Federal Statutory Bodies and the Management of Subsidiary Companies and Financial Management, Series 1 .

Nunnally, J. C. (1978). Psychometric theory (2nd ed.). New York: McGrawHill. 
Pailler, S. (2018). Re-election incentives and deforestation cycles in the Brazilian. Journal of Environmental Economics and Management, 88, 345-365.

Paine, L. S. (1994). Managing for organizational integrity. Harvard Business Review, 106-117.

Pallant, J. (2016). SPSS survival manual (6 ${ }^{\text {th }}$ ed.). London: McGraw Hill Education.

Petrick, J. A., \& Quinn, J. F. (2000). The integrity capacity construct and moral progress in business. Journal of Business Ethics, 23, 3-18.

Rosli, M. H., Aziz, M. A. A., Mohd, F., \& Said, J. (2015). Integrity systems in Malaysian Public Sector: An empirical finding. Procedia Economics and Finance, 28, 260-265.

Rossouw, D., Van Vuuren, L., Abdullah, H. A. G., \& Mohamad Zainol Abidin, A. (2011). Business Ethics. Oxford: Oxford University Press.

Ryan, C., \& Ng, C. (2000). Public sector corporate governance disclosures: An examination of annual reporting practices in Queensland. Australian Journal of Public Administration, 59(2), 11-23.

Said, J., \& Omar, N. (2014). Corporate integrity system: Comparative analysis of two giant government linked companies. Procedia - Social and Behavioral Sciences, 145, 12-17.

Sajari, A., Haron, H., \& Ismail, I. (2016). Role of chief integrity officer in Malaysian public sector. The National Conference for Postgraduate Research, University Malaysia Pahang (pp. 135-141).

Sajari, A., Haron, H., Ismail, I., \& Chambers, A. (2019). Quality of chief integrity officer, ethical climate and the level of ethics and integrity in the Malaysian public sector. In FGIC 2nd Conference on Governance and Integrity, Yayasan Pahang, Kuantan, Pahang (pp. 423-458). 
Sarkar, H., \& Hasan, M. A. (2001). Impact of corruption on the efficiency of investment: Evidence from a cross-country analysis. Asia-Pacific Development Journal, 8(2), 111-116.

Seidman, H. (1954). The government corporation: Organization and controls. Public Administration Review, 14(3), 183-192.

Seligson, M. A. (2002). The impact of corruption on regime legitimacy: A comparative study of four Latin American countries. The Journal of Politics, 64(2), 408-433.

Shu, W., Chen, Y., Lin, B., \& Chen, Y. (2018). Does corporate integrity improve the quality of internal control? China Journal of Accounting Research, 11(4), 407-427.

Steinberg, R. M. (2011). Governance, risk management, and compliance: It can't happen to us - avoiding corporate disaster while driving success. Hoboken, NJ: John Wiley \& Sons.

Thynne, I. (2006). Statutory bodies: How distinctive and in what ways? Public Organization Review, 6(3), 171-184.

Ucar, E., \& Staer, A. (2020). Local corruption and corporate social responsibility. Journal of Business Research, 116, 266-282.

Wan, P., Chen, X., \& Ke, Y. (2020). Does corporate integrity culture matter to corporate social responsibility? Evidence from China. Journal of Cleaner Production, 259, 120877.

Wieland, J. (2005). Corporate governance, values management, and standards: A European perspective. Business \& Society, 44(1), 74-93.

Zafarullah, H., \& Siddiquee, N. A. (2001). Dissecting public sector corruption in Bangladesh: Issues and problems of control. Public Organization Review, 1(4),465-486. 